\title{
FDI, Trade and Economic Development in Pakistan
}

\author{
${\text { Muhammad Afzal }{ }^{\text {a,* }} \text { \& Shoaib Ahmad }}^{\text {b }}$ \\ ${ }^{a}$ Department of Economics, Preston University, Islamabad 44000, Pakistan \\ ${ }^{b}$ Department of Management, Preston University, Islamabad 44000, Pakistan
}

\begin{abstract}
This paper examined the relationship between FDI, imports, exports, terms of trade and investment in Pakistan for the period 1990-2015. Results show that an increase in all these factors will contribute significantly to FDI flows that may help the Pakistan's economy. FDI has negative and significant impact on GDP. Exports have an insignificant effect that may imply that historically economy had led exports more than the exports led the economy. More important fact is that world economic conditions play a crucial role in the macroeconomic performance. When these conditions are favorable, not only the economy but also the trade grow. Though global financial crisis did not seriously affect Pakistan's economy, Pakistan faced multifaceted challenges on external and internal fronts notably fight against extremism, energy crisis and uncertain external inflows. There is a need to pay more attention to domestic situation than to look abroad for financial assistance since FDI is not an unmixed blessing.
\end{abstract}

Keywords: FDI, Trade, Investment, Robust Least Squares

\section{Introduction}

Foreign aid and foreign investment are two important sources of foreign capital. The former comprises grants and low interest rates loans and latter consists of foreign direct investment (FDI) and foreign portfolio investment (FPI). FDI plays more dominant role than FPI. Over the last decades there have been visible changes in the patterns and trends of these foreign capital flows to developing countries (Le and Attaullah 2002). The flow of private capital in the form of foreign direct investment was an important aspect of globalization in the 1990s which is a vital source of development financing that contributes to productivity gains in the form of new investment, better technology, management expertise and export markets. In the neoclassical growth model, FDI promotes economic growth by increasing the volume of investment and its efficiency. Therefore, developing and least developed countries seek to attract FDI for several benefits it brings into the host country economy. Keeping in view the economic benefits and importance of FDI for promoting economic growth, most of the countries have formulated wide-reaching changes in national policies to attract FDI (Sahoo 2006).

Several international surveys have shown that the single largest component of net capital inflows to emerging markets is foreign direct investment (FDI). These are long term investments from investors, multinational corporations (MNCs) and other bodies from outside the country. It has been argued that foreign direct investment not only provides an initial capital inflow to support the balance of payments (BoPs) of the host country but also fills the saving-investment gap, enhances productivity, transfers advanced technology and management skills that promote economic growth These alleged benefits convinced the policy makers in developing countries to liberalize domestic economies to attract foreign capital.

Large number of studies have examined FDI role from different perspectives. Majority of the studies has attributed positive role to FDI. FDI promotes economic growth through its impact on productivity, employment generation,

\footnotetext{
* Corresponding author.

E-mail address: profafzal@gmail.com (Muhammad Afzal)
} 
addition to the country's capital stock and trade growth. It promotes forward and backward linkages within the domestic economy (Hale and Long, 2006; UNIDO, 2006; Pacheco-López, 2005; Ram and Zhang, 2002; World Bank, 1998; Mello, 1997). FDI helps a country integrate into global economic networks by technology transfer and improvement in total factor productivity and promotes growth by creating a better economic environment that promotes exports (Schneider, 2005; UNCTAD, 2002; Sun and Parikh, 2001). However, the growth-enhancing effect of FDI is not obvious that may vary from country to country and in some cases it may even adversely affect the growth process and the contribution of foreign direct investment depends on the ability of the host economy to absorb foreign technology. It has been generally highlighted that FDI can promote growth and encourage exports through the key role of creating a better economic environment (Xu, 2000; Aitken and Harrison, 1999; De Mello, 1999; Borensztein et. al., 1998; UNCTAD, 2002). Many studies have examined the FDI role in stimulating innovation and increasing trade as well as enhancing economic efficiency (Ghirmay et. al., 2001; Bayoumi and Lipworth, 1997; Balasubramanyam et. al., 1996 and 1999). The most frequently cited criticisms against FDI include the environmental damage it can cause to host countries like substantial damage that has been done in some primary sectors in order to provide goods for advanced country markets Other potential disadvantages of FDI include how FDI may affect local labor standards in recipient countries and cultural-political issues such as the influence of MNEs making the investments exert over host country governments. There has been a lot of debate on the impact of FDI on economies. Critics of FDI argue that the MNCs bringing FDI generally monopolize resources, supplant domestic enterprises, introduce inappropriate technology and create balance of payments problems though large remittances (Sahoo 2006).

\section{FDI in Pakistan}

Foreign Direct Investment in Pakistan increased by 2677.90 USD Million in 2015. Foreign Direct Investment in Pakistan averaged 2623.93 USD Million from 2010 until 2015, reaching an all-time high of 3184.30 USD Million in 2010 and a record low of 2009 and 10 USD Million in 2012. Foreign Direct Investment in Pakistan is reported by the State Bank of Pakistan. FDI fell by 45\% in 2016.

Pakistan has been receiving substantial foreign aid since 1950s at mixed terms and conditions. Foreign aid has contributed significantly to Pakistan's economic development but at the same time much price has been paid in terms of debt servicing and perpetuation of external dependence. During 1970s and 1980s current account deficit was also financed by tremendous workers' remittances besides foreign aid. Now remittances have declined and foreign aid is not available at concessional terms after the end of cold war particularly to those countries like Pakistan that were deeply engaged in the conflict between the West and the Soviet Union (Afzal 2011).Since late 1980s foreign investment both direct and portfolio, has assumed immense importance as a source of foreign capital to developing countries (World Bank 1991). Total foreign direct investment in 1997 amounted to \$349.2 billion against US \$ 203.8 billion in 1996. Various governments have offered generous incentives to foreign investors because they will not invest unless they expect a high return as they perceive high risks keeping in view the fragile macroeconomic performance and political instability. Substantial benefits in the shape of capital, advance technology, new managerial and technical skills, marketing expertise, employment generation and linkages with the outside world are the potential advantages of foreign investment (Government of Pakistan (GOP), 1991-92, 88). During 1989- 1999, US enjoyed the principal share followed by UK and Japan (GOP 2000-01).Table 1 and Table 2 show sector-wise and country-wise FDI Inflows (\$ Million) in Pakistan during the period 2007-16. In this period financial services and communication has lion share followed by oil and other sectors. During the latter period US has the largest share followed by UEA and Norway. Figure 1 shows Pakistan FDI as percent of GDP for the period 1990-2014. The period 2005-2008 had the largest FDI share.

Studies on the FDI in Pakistan (Majeed and Ahmad, 2008; Khan, 2007; Le and Attaullah, 2002; Akhtar, 2000; Aqeel and Nishat, 2005; Khan and Kim,1999; Shabbir and Mehmood,1992) among other have analysed different aspects of foreign investment in Pakistan. Le and Attaullah (2002) have reviewed the trend of foreign capital inflows to Pakistan. The study finds an insignificant impact of foreign capital, foreign aid and foreign private investment on economic performance of Pakistan. Akhtar (2000) has studied the determinants of FDI in Pakistan. Shabbir and Azher, (1992) and Afzal (2004a) supported the displacement hypothesis.which posits that foreign financial flows discourage saving and resource mobilization efforts. Khan and Kim have analyzed policy issues and operational implications of FDI. 
Table 1. Sector Wise FDI Inflows (\$ Million)

\begin{tabular}{crrrrrrrrrr}
\hline Year & 2007 & 2008 & 2009 & 2010 & 2011 & 2012 & 2013 & 2014 & 2015 & 2016 \\
\hline Oil \& Gas & 634.8 & 775.0 & 740.6 & 512.2 & 629.4 & 559.6 & 502.0 & 246.1 & 261.6 & 37.8 \\
Financial & $1,864.9$ & 707.4 & 163.0 & 310.1 & 64.4 & 314.2 & 192.8 & 256.4 & 28.2 & 13.5 \\
Business & & & & & & & & & & \\
Textiles & 30.1 & 36.9 & 27.8 & 25.3 & 29.8 & 10.0 & $(0.2)$ & 43.9 & 21.0 & 6.3 \\
Trade & 175.9 & 166.6 & 117.0 & 53.0 & 25.3 & 5.7 & $(3.2)$ & 50.0 & 30.1 & 8.5 \\
Construction & 89.0 & 93.4 & 101.6 & 61.1 & 72.1 & 46.0 & 28.8 & 53.5 & 36.3 & 1.8 \\
$\quad$ Power & 70.3 & 130.6 & $(120.6)$ & 155.8 & $(84.9)$ & 28.4 & 71.4 & 201.7 & 566.6 & 61.7 \\
Chemicals & 79.3 & 74.3 & 112.1 & 30.5 & 96.3 & 71.6 & 94.9 & 55.3 & 64.6 & 8.4 \\
$\quad$ Transport & 74.2 & 93.2 & 132.0 & 104.6 & 18.7 & 44.1 & 2.7 & 6.2 & 36.8 & 3.2 \\
Communication & $1,626.8$ & 879.1 & 291.0 & $(34.1)$ & $(312.6)$ & $(385.7)$ & 434.2 & 45.1 & 195.2 & 24.2 \\
(IT\&Telecom) & & & & & & & & & & \\
$\quad$ Others & 764.5 & 763.4 & 586.3 & 416.3 & 282.2 & 765.5 & 375.2 & $(107.0)$ & 40.7 & 84.0 \\
Total including Pvt. & $5,409.8$ & $3,719.9$ & $2,150.8$ & $1,634.8$ & 820.7 & $1,456.4$ & $1,698.6$ & 851.2 & $1,281.1$ & 249.4 \\
$\quad$ Proceeds & & & & & & & & & & \\
Privatization & 133.2 & 0.0 & 0.0 & 0.0 & 0.0 & 0.0 & 0.0 & 0.0 & 0.0 & 0.0 \\
$\quad$ Proceeds & & & & & & & & & & \\
FDI Excluding & $5,276.6$ & $3,719.9$ & $2,150.8$ & $1,634.8$ & 820.7 & $1,456.4$ & $1,698.6$ & 851.2 & $1,281.1$ & 249.4 \\
Pvt. Proceeds & & & & & & & & & & \\
\hline Sourc: GOP, Bo & & & & & & &
\end{tabular}

Source: GOP, Board of Investment Pakistan 2016

Aqueel and Nishat (2005) examined the role of different policy variables (tariff rate, exchange rate, credit to private sector, trade, fiscal and financial sector liberalization ) in attracting FDI in Pakistan and have concluded that these policy variables have played significant role in attracting and determining FDI growth in both short and long-run in Pakistan for the period 1961-2003. Majeed and Ahmad (2008) analyzed the relationship between FDI and exports and their determinants for 49 countries including Pakistan for the period 1970-2004 and have concluded the absence of substitution relationship between FDI and exports.

Table 2. Country Wise FDI Inflows (\$ Million)

\begin{tabular}{lllllllllll}
\hline \multicolumn{1}{c}{ Country } & 2007 & 2008 & 2009 & 2010 & 2011 & 2012 & 2013 & 2014 & 2015 & 2016 \\
\hline USA & $1,309.3$ & 869.9 & 468.3 & 238.1 & 227.7 & 227.1 & 212.1 & 209.0 & $(65.5)$ & 58.8 \\
UK & 460.2 & 263.4 & 294.6 & 207.1 & 205.8 & 633.0 & 157.0 & 174.3 & 79.8 & 21.5 \\
U.A.E & 589.2 & 178.1 & 242.7 & 284.2 & 36.6 & 22.5 & $(47.1)$ & 216.4 & 164.2 & 38.1 \\
Japan & 131.2 & 74.3 & 26.8 & 3.2 & 29.7 & 30.1 & 30.1 & 71.1 & 21.6 & 5.2 \\
Hong Kong & 339.8 & 156.1 & 9.9 & 125.6 & 80.3 & 242.6 & 228.5 & 83.4 & 130.9 & 0.9 \\
Switzerland & 169.3 & 227.3 & 170.6 & 110.5 & 127.1 & 149.0 & 209.8 & 2.8 & 76.0 & 5.4 \\
Saudi Arabia & 46.2 & $(92.3)$ & $(133.8)$ & 6.5 & $(79.9)$ & 3.2 & $(40.1)$ & $(64.8)$ & $(102 . .2)$ & $(31.8)$ \\
Germany & 69.6 & 76.9 & 53.0 & 21.2 & 27.2 & 5.5 & $(5.7)$ & $(20.3)$ & $(33.0)$ & $(1.4)$ \\
Korea (South) & 1.2 & 2.3 & 2.3 & 7.7 & 25.4 & 25.8 & 24.4 & 14.3 & $(18.6)$ & $(1.3)$ \\
Norway & 274.9 & 101.1 & 0.4 & $(48.0)$ & $(275.0)$ & $(258.4)$ & $(21.6)$ & 2.7 & 172.3 & 20.0 \\
China & 13.7 & $(101.4)$ & $(3.6)$ & 47.4 & 126.1 & 90.6 & 695.8 & 255.3 & 593.9 & 90.8 \\
\hline
\end{tabular}

Source: GOP, Board of Investment Pakistan 2016

Similarly studies on imports and exports of Pakistan's economy (Afzal, 2011, 2008, 2006; Afzal and Hussain, 2010; Bader, 2006; Atique and Ahmad, 2003; Akhtar and Malik, 2000 among others) have investigated different aspects of trade. Neither of the above of studies has examined the relationship between trade and FDI and also the impact of FDI and other variables on economic growth of Pakistan. Therefore this paper has twin objectives as mentioned above. 
This study is important because many studies on the exports promotion and FDI role have attributed a positive role of the two on economic growth.

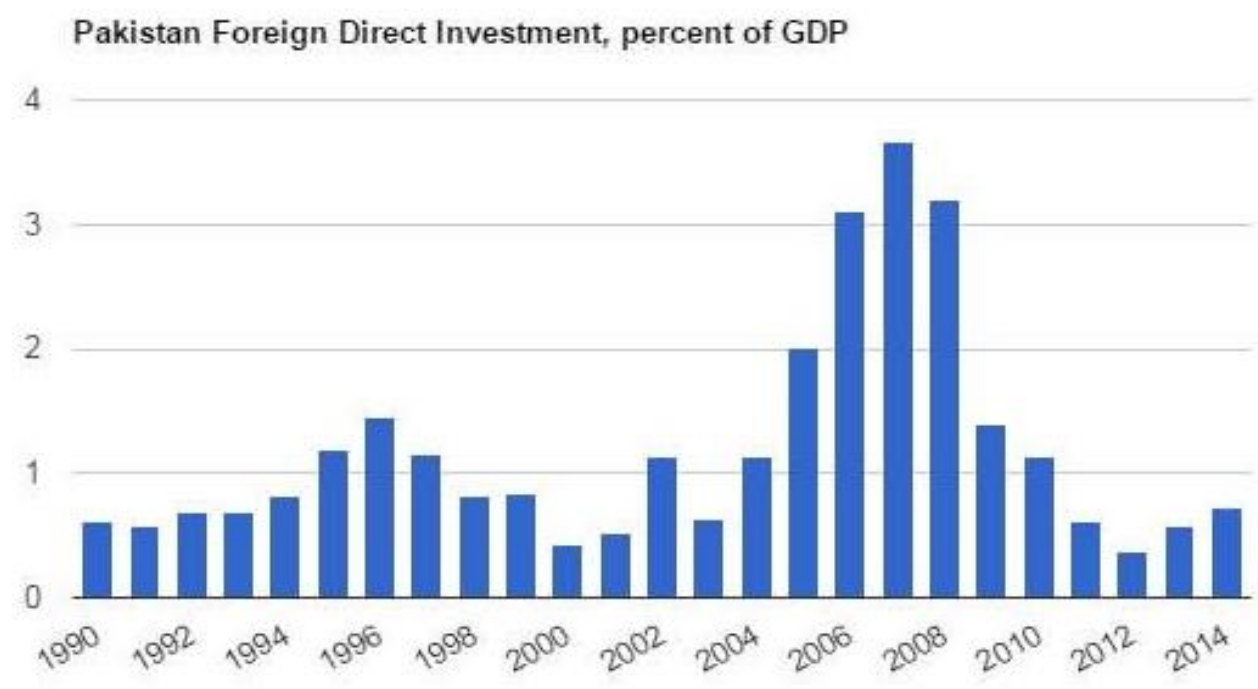

Fig. 1 Pakistan Foreign Direct Investment (\% of GDP) Source: TheGlobalEconomy.com, The World Bank

\section{Model}

Since macroeconomics is based on general equilibrium approach, it is a well known fact that macroeconomic variables are interwoven and interact with each other and it is dangerous to examine these variables in isolation that may lead to misleading results, conclusions and policy prescriptions. Macroeconomic variables are influenced by a host of factors. It is difficult to consider all potential variables because the data may not be available and even if available their joint impact may be insignificant. Therefore modest number of variables is included in a model in order to render the model parsimonious.

During 1960s, 1970s, and 1980s foreign aid comprising grants and low interest rate served as a main source of external financial assistance to help the recipient countries to realize the development and growth goals. FDI and FPI assumed immense importance in 1990s that marked the beginning of trade liberalization and globalization. FDI has been claimed to be an important source of foreign capital to finance development and growth notably in the developing countries. There is vast literature on the determinants, benefits and costs of FDI. These may vary across the countries depending on the socio-economic-political conditions of a country(s). FDI has close relationship with macroeconomic performance conspicuously measured by investment scenario, imports, and exports behavior, and terms of trade besides other factors.

\subsection{Investment}

The need for raising savings and consequently investment in accelerating economic growth is universally acknowledged. Rapid economic growth is the major economic objective of any development plan in a developing country, which in turn depends on substantial saving and investment because these factors play dominant role in accelerating economic growth. High rates of domestic saving are important because savings provide most of the funds for investment. Since capital stock is not available for most developing countries because of inherent difficulties of measurement, gross investment is used for capital. Since aggregate net investment has certain theoretical and empirical problems. Moreover, there are no data available on annual depreciation rates at hand Afzal (2004b). 


\subsection{Terms of Trade}

Terms of trade also play a significant role in the economic growth. Favorable terms of trade (TOT) benefit a country as its exports fetch more goods in exchange and its capacity to import increases. Adverse TOT implies that the real opportunity cost of a unit of import rises when its export prices decline relative to its import prices. The adverse TOT drains out the resources because to maintain old level of imports more exports are needed and unfavorable TOT are an important factor in the balance of trade deficit ( Afzal and Ali 2008).

\subsection{Exports and Imports}

Almost all countries are dependent on trade because of different distribution of resources. Trade is not only desirable but also inevitable because countries have to cater to the growing needs of their economies. On the basis of nineteenth century trade pattern, traditional trade theory was termed an "engine of growth". However, as the conditions changed later, economists emphasized the role of trade as "handmaiden of growth". According to Afzal (2006) international trade plays a dynamic role. It widens the market, improves the division of labour and stimulates technical innovation and thus the country enjoys increasing returns and economic development. These arguments form the basis of the export-led hypothesis that has been widely discussed and empirically tested, mainly in a cross-country context.

Imports and exports are two sides of the same coin. To study the foreign trade regime of a country, a better picture could be obtained if imports are studied alongside exports. Imports play an important role in the investment environment and thus industrial development and economic growth. Therefore, study of the behaviour of imports is necessary not only to see the demand for imports that can determine the dependence on the foreign countries supply of raw materials, semi-finished and finished goods that have implications for balance of payments scenario but also serve as guide for comparing the purchasing power of exports that is terms of trade. Therefore, study of imports is highly desirable in order to have a pragmatic picture of the foreign trade situation that will help in formulating policies During 1990s as Pakistan embarked on trade liberalization program, exports growth exceeded imports growth but imports increased in value terms resulting in current account deficit to the tune of 5\% of GDP (Afzal 2011).

It assumed that FDI is dependent on imports, exports, terms-of-trade (TOT) and investment as percentage of GDP. Therefore, the following model of FDI is proposed:

$\operatorname{lnfdi}=\beta_{0}+\beta_{1}$ lnimports $+\beta_{2}$ lnexports $+\beta_{3} \operatorname{lnTOT}+\beta_{4} \operatorname{lninv}+\mu$

Similarly the relationship between FDI and economic growth represented by GDP is also explored. Besides variables entered in equation (1) also influence GDP. Now $\mathrm{US}_{\mathrm{y}}$ is used as a proxy for world economic conditions. This is an exogenous variable that can influence the economic growth in a multiplicity of ways as is evident from the various international events of crucial importance like $9 / 11$ events, globalization etc. These events can significantly influence the exports, imports and exchange rate of a country. The rising oil- prices created rising and persistent balance of payments problems for LDCs (less developed countries) that have burdened these countries with heavy debt whose service over the years has become unbearable.

Exceptional rise in oil prices that increased from $\$ 55$ per barrel in 2007 to over $\$ 120$ per barrel (118.18\% increases) in May 2008 and depreciation of dollar against major currencies resulted in huge import cost in countries like Pakistan and passing on of this cost to consumers propelled inflation (GOP 2007-08). Therefore, the following model is suggested:

$\operatorname{lny}=\beta_{0}+\beta_{1}$ lnimports $+\beta_{2}$ lnexports $+\beta_{3} \operatorname{lnfdi}+\beta_{4} \operatorname{lninv}+\varepsilon$

\subsection{Robust Least Squares}

Ordinary least squares estimators are sensitive to outliers. This sensitivity can result in coefficient estimates that do not accurately reflect the underlying statistical relationship. Robust least squares consist of diversity of regression 
methods which are robust, or less sensitive to outliers. M-estimation, S-estimation, and MM-estimation are three methods that EViews 8 offers. The three methods differ in their emphases:

M-estimation addresses dependent variable outliers where the value of the dependent variable differs markedly from the regression model norm (large residuals). The traditional least squares estimator is computed by finding coefficient values that minimize the sum of the squared residuals. S-estimation is a computationally intensive procedure that focuses on outliers in the regressor variables (high leverages). MM-estimation is a combination of S-estimation and M-estimation. The procedure starts by performing S-estimation, and then uses the estimates obtained from Sestimation as the starting point for M-estimation. Since MM-estimation is a combination of the other two methods, it addresses outliers in both the dependent and independent variables. Least squares diagnostics for outlier detection are given by leverage plots and influence statistics.

\subsection{Data}

Data on all above-mentioned variables were gathered from Government of Pakistan, Economic Survey (1992-93, 1997-98, 2005-2006, 2009-2010, 2015-2016 issues). Data on US $_{\mathrm{y}}$ were obtained from IMF CD-ROM 2016. The period of the study is $1990-2015$.

\section{Estimation Results}

The estimation results of equations 1 and 2 have been presented in Table 1 and Table 2. Table 1 shows the results of the factors that affect FDI in Pakistan. All the underlying variables that is imports, exports, TOT and investment have positive impact on FDI in Pakistan. Besides the coefficients of the fore-mentioned variables are all significant suggesting that these are the crucial determinants of FDI. An increase in all these factors will contribute significantly to FDI flows which are supposed to help the Pakistan's macroeconomy.

Table 1. Dependent Variable lnfdi

Robust Least Squares Method MM-estimation method

\begin{tabular}{ccccc}
\hline Variable & Coefficient & Std. Error & z-Statistic & Prob. \\
\hline $\mathrm{C}$ & -52.49 & 11.07 & -4.74 & 0.0000 \\
lnimports & 1.07 & 0.43 & 2.49 & 0.0126 \\
lnexports & 0.16 & 0.07 & 2.19 & 0.0283 \\
lntot & 3.43 & 0.98 & 3.47 & 0.0005 \\
lninv & & 1.28 & 7.25 & 0.0000 \\
\hline \multicolumn{7}{c}{} & 9.34 & Robust Statistics \\
\hline $\mathrm{R}^{2}$ & 0.67 & Adjusted $\mathrm{R}^{2}$ & 0.60 \\
$\mathrm{Rw}^{2}$ & 0.80 & Adjust $\mathrm{Rw}^{2}$ & 0.80 & \\
Deviance & 6.68 & Schwarz criterion & 34.21 & \\
$\mathrm{Rn}^{2 \mathrm{~s}}$ tatistic & 62.50 & Prob $\left(\mathrm{Rn}^{2}\right)$ & 0.000 & \\
\hline
\end{tabular}

Keeping in view the unstable situation of the economy, FDI plays a benign role. FDI is needed to finance development plans that may have spill-over effects on the economy. Of all the four factors, investment has the largest coefficient meaning that promotion of investment will contribute significantly to attract FDI. The coefficient of imports exceeds exports implying much dependence on imports. Afzal and Ali (2008) have arguably demonstrated that historically exports have not figured prominently in Pakistan mainly attributable to composition and concentration of exports in few commodities and markets.

The impact of FDI in addition to other variables has been shown in Table 2. FDI has negative and significant impact on GDP. Exports also have an insignificant effect on GDP that is in agreement with Afzal and Ali (2008) conclusion that economy had led exports more than the exports-led the economy. Economic growth has responded more to the 
emphasis on domestic market rather than on trade. $\mathrm{US}_{\mathrm{y}}$ has the largest coefficient meaning that world economic conditions play a crucial role in the macroeconomic performance. When these conditions are favourable, not only the economy but also the trade grows. Global financial crisis that originated in the mid-2007 had adversely affected the world economies and Pakistan was not an exception though its incidence was not as severe as it had been in other countries. Government of Pakistan (2011-12) reported that the global financial crisis did not seriously affect Pakistan's economy because of its lower exposure to international finance. However, Pakistan faced multifaceted challenges on external and internal fronts notably fight against extremism, energy crisis and uncertain external inflows.

\begin{tabular}{|c|c|c|c|c|}
\hline \multicolumn{5}{|c|}{$\begin{array}{l}\text { Method Robust Least Squares } \\
\text { Method: MM-estimation }\end{array}$} \\
\hline Variable & Coefficient & Std. Error & z-Statistic & Prob. \\
\hline $\mathrm{c}$ & -10.04 & 1.38 & -7.26 & 0.0000 \\
\hline $\operatorname{lnfdi}$ & -0.11 & 0.02 & -6.87 & 0.0000 \\
\hline lnimports & 0.53 & 0.08 & 6.82 & 0.0000 \\
\hline lnexports & 0.0002 & 0.006 & 0.044 & 0.9650 \\
\hline $\operatorname{lninv}$ & 0.44 & 0.14 & 3.28 & 0.0010 \\
\hline $\operatorname{lnus}_{\mathrm{y}}$ & 1.90 & 0.23 & 8.16 & 0.0000 \\
\hline \multicolumn{5}{|c|}{ Robust Statistics } \\
\hline$\overline{\mathrm{R}^{2}}$ & 0.84 & Adjusted $\mathrm{R}^{2}$ & 0.81 & \\
\hline $\mathrm{Rw}^{2}$ & 0.99 & Adjust $\mathrm{Rw}^{2}$ & 0.99 & \\
\hline Deviance & 0.04 & Schwarz criterion & 44.33 & \\
\hline $\mathrm{Rn}^{2 \mathrm{~s}}$ tatistic & 14057.16 & $\operatorname{Prob}\left(\mathrm{Rn}^{2}\right)$ & 0.000 & \\
\hline
\end{tabular}

Imports also have a positive significant coefficient. Excepting few years Pakistan has faced a persistent trade deficit. Pakistan industry has relied heavily on imports. After US $\mathrm{y}_{\mathrm{y}}$ investment has the higher coefficient than in Table 1 . This is in agreement with the literature. It is difficult to find any country, which was able to grow at high rate for a long period without experiencing high rates of capital formation and/or high rates of savings (Afzal 2004a). The bottom portion of the output in Table 1 and Table 2 shows the goodness-of-fit and adjusted measures which indicate that the model explains for roughly $60-80 \%$ and $81-99 \%$ of the variation in the model in the two tables respectively. The $\mathrm{Rn}^{2}$ statistic and corresponding $p$-value of 0.000 indicate strong rejection of the null hypothesis that all non-intercept coefficients are equal to zero.

\section{Conclusions}

This paper examined the relationship between trade factors and investment. Imports, exports, terms of trade and investment have positive impact on FDI in Pakistan suggesting that an increase in all these factors will contribute significantly to FDI flows that may help the Pakistan's economy. FDI has negative and significant impact on GDP. Exports also have an insignificant effect on GDP that may imply that historically economy had led exports more than the exports-led the economy. $\mathrm{US}_{\mathrm{y}}$ has the largest coefficient meaning that world economic conditions play a crucial role in the macroeconomic performance.

When these conditions are favorable, not only the economy but also trade grows. Though global financial crisis did not seriously affect Pakistan's economy due to its lower exposure to international finance, Pakistan faced multifaceted challenges on external and internal fronts notably fight against extremism, energy crisis and uncertain external inflows. There is a need to pay more attention to domestic situation than to look abroad for financial assistance since FDI is not an unmixed blessing. 


\section{References}

Afzal, M. (2011). Exports and economic growth in Pakistan: Historical and empirical evidence. Germany, AV Akademikerverlag.

Afzal, M. and Ejaz Hussain (2010). Export-led growth hypothesis: Evidence from Pakistan. Indian Journal of Quantitative Economics, 8(1), 130-147.

Afzal, M (2008). Long-run relationship between imports and exports: Evidence from Asian countries. Singapore Economic Review, 53(2), 1-19.

Afzal, M \& Karamat Ali (2008). A historical evaluation of export-led growth policy in Pakistan. Lahore Journal of Policy Studies, 2(1), 69-82.

Afzal, M (2006). Causality between exports, world income and economic growth in Pakistan. International Economic Journal, 20 (1), 63-77.

Afzal, M (2004a). Estimating saving and investment functions in Pakistan. Philippine Review of Economics, 41 (1), 67-78.

Afzal, M. (2004b). Exports-economic growth nexus: Pakistan's experience. Indian Journal of Business and Economics, 3 (2), 315-340.

Aitken, Brian J. and Ann E. Harrison (1999). Do domestic firms benefit from direct foreign investment? Evidence from Venezuela. American Economic Review, 89, 605 - 618.

Akhtar, S., and Malik, F., (2000). Pakistan's trade performance vis-à-vis its major trading partners. The Pakistan Development Review, 39(1), 37-50.

Akhtar, M. H., (2000). The determinants of foreign direct investment in Pakistan: An econometric analysis. The Lahore Journal of Economics, 5(2), 1-22.

Aqueel, A. and Nishat, M. (2005), The determinants of foreign direct investment in Pakistan. Paper presented at the $20^{\text {th }}$ Annual General meeting and Conference, $10^{\text {th }}-12^{\text {th }}$ January 2005, Pakistan Society of Development Economics, Islamabad.

Atique Zeshan, Ahmad H.Mohsin, and Azhar Usman (2004).The impact of FDI on economic growth under foreign trade regimes: A case study of Pakistan. The Pakistan Development Review, 43(4), 707-718.

Atique, Z., and Ahmad, M. H (2003). The supply and demand for exports of Pakistan, the polynomial distributed lag model (PDL) Approach. The Pakistan Development Review, 42(4), 961-972.

Bader, S (2006). Determining import intensity of exports for Pakistan. SBP (State Bank of Pakistan) Research Bulletin, 2(2), 363-381.

Balasubramanyam, V. N., Salisu, M., and Sapsford, D. (1999). Foreign direct investment as an engine of growth. The Journal of International Trade and Economic Development, 8, 27-40.

Balasubramanyam, V., Salisu, M. and Sapsford, D. (1996). Foreign direct investment and growth in EP and IS Countries. Economic Journal, 106: 92-05.

Bayoumi, T. and Lipworth, G. (1997). Japanese foreign direct investment and regional trade. IMF Working Paper, WP/97/103.

Borensztein, E.J., De Gregorio, J., and Lee, J.W. (1998). How does foreign direct investment affect economic growth? Journal of International Economics, 45, 115-135.

De Mello, L R., Jr., (1999), Foreign direct investment-led growth: Evidence from time series and panel data. Oxford Economic Papers, 51, 133-151.

De Mello Jr., L.R. (1997). Foreign direct investment in developing countries and growth: A selective survey. The Journal of Development Studies, 34(1): 1-34.

Ghirmay, T., Grabowski, R., and Sharma, C. (2001). Exports, investment, efficiency and economic growth in LDCs: An empirical investigation. Applied Economics, 33(6),689- 700. 
Government of Pakistan, Economic Survey (various issues). Islamabad, Ministry of Finance, Economic Advisor Wing Government of Pakistan (2016). Board of Investment

Hale, G. and Long, C. (2006). What determines technological spillovers of foreign direct investment: Evidence from China. Yale University Economic Growth Center Discussion Paper No. 9346, Yale University.

IMF(2016). CD-ROM 2016 Washington D.C.

Khan, M. and Y.H. Kim (1999). Foreign direct investment in Pakistan: Policy issues and operational implications. ADB, Manila, ERCD Report Series No. 66.

Khan Arshad, (2007).Foreign direct investment and economic growth: The role of domestic financial sector. Islamabad PIDE Working Paper N o.18.

Le Minh Hang and Ali Ataullah (2002). Foreign capital and economic performance of Pakistan. Lahore Journal of Economics, 7(10), 1-32.

Shabbir Tayyab and Mahmood. Azhar (1992). The effects of foreign private investment on economic growth in Pakistan. The Pakistan Development Review, 31(4), 831-841.

Sahoo Pravakar (2006). Foreign direct investment in South Asia: Policy, trends, impact and determinants. $A D B$ Institute Discussion Paper No. 56

Majeed, M.Tariq and Eatzaz Ahmad (2008), Exports and FDI in developing countries: Substitutes or compliments. Paper presented at the $23^{\text {th }}$ Annual General meeting and Conference, $10^{\text {th }}-12^{\text {th }}$ March12-14, 2008, Islamabad Pakistan Society of Development Economics.

Pacheco-López, P. (2005). Foreign direct investment, exports and imports in Mexico. World Economy, 28 (8), $1157-$ 1172.

Ram, R. and Zhang, K.H. (2002). Foreign direct investment and economic growth: Evidence from cross-country data for the 1990s. Economic Development and Cultural Change, 51,205-215.

Sun, H. and Parikh, A. (2001). Exports, inward foreign direct investment and regional economic growth in China. Regional Studies, 35 (3), 187-196.

Schneider, P. H. (2005), International trade, economic growth and intellectual property rights: A panel data study of developed and developing countries. Journal of Development Economics, 78, 529- 547.

UNCTAD (2002). World Investment Report 2002: Transnational corporations and export competitiveness. United Nations Conference on Trade and Development, Geneva.

UNIDO (2006). Africa foreign investor survey 2005, UNIDO, Vienna, Austria.

Xu, B. (2000), Multinational enterprises, technology diffusion, and host country productivity growth. Journal of Development Economics, 62,477-93.

World Bank, (1998). World Development Report, New York, Oxford University Press.

World Bank, (1991). World Development Report, New York, Oxford University Press. 